\title{
CLIMATE CHANGE CAUSING FOOD INSECURITY IN EAST AFRICA: TRADITIONAL AND NON-TRADITIONAL STRATEGIES TO SOLVE THE PROBLEM
}

\author{
NATAMBA, L. ${ }^{1}-$ ZHANG, $\mathrm{W}{ }^{*}-\mathrm{ZHANG} \mathrm{J}^{2}{ }^{2}-\mathrm{ZHAO}, \mathrm{X}{ }^{3}$ \\ ${ }^{1}$ Laboratory of Water Resource and Hydrology, College of Resources and Environment, \\ Southwest University, Beibei, Chongqing 400715, China \\ (e-mail: natambaleo@gmail.com; phone: +86-136-383-5800/+256-77-417-5510) \\ ${ }^{2}$ Department of Environmental Science and Engineering, College of Resources and \\ Environment, Southwest University, Beibei, Chongqing 400715, China \\ (e-mail: jzhzhang@swu.edu.cn; phone: +86-138-833-8113) \\ ${ }^{3}$ Department of Environmental Science and Technology, College of Resources and \\ Environment, Southwest University, Beibei, Chongqing 400715, China \\ (e-mail: zxl@swu.edu.cn; phone: +86-138-8397-9897) \\ *Corresponding author \\ e-mail: swuwater@126.com; phone: +86-136-3782-2374 \\ (Received 23 ${ }^{\text {rd }}$ Jan 2018; accepted $6^{\text {th }}$ Apr 2018)
}

\begin{abstract}
In East Africa, climate change is understood as a period of drought or floods. In real sense, it is the universal changes in the behavior of weather patterns based on statistical predictions for a long period of time. The region has experienced severe climatic changes of droughts, floods that negatively affect agricultural production causing food insecurity. This has caused both internal and regional migrations across East African borders especially by pastoral groups. These impelled migrations often cause insecurity. Literature searches have been used to gather information about what has been done and what should be done to safeguard communities from food insecurity caused by climate shocks. Results show that over $31 \%$ of the people are affected by undernourishment, an indicator of food insecurity and this has been to a great extent brought about by destruction of ecosystems which has enhanced climate change. Proposed mitigation and adaptation strategies include traditional and non-traditional measures. Policy issues have also been emphasized. In conclusion, destruction of fragile ecosystems contributes to climate change. Failure to adopt new technologies and neglect of some traditional technologies are greatly responsible for food insecurity in East Africa.
\end{abstract}

Keywords: adaptation, anthropogenic, ecosystem, migrations, mitigation

\section{Introduction}

In many parts of East Africa, most of the people perceive climate change as real due to variability in terms of temperature rise, rainfall reductions, erratic rains and prolonged droughts (Gichangi et al., 2015; Bryan et al., 2013; Souverijns et al., 2016; Leal et al., 2017). This is also a result of catastrophic rains characterized by storms, floods and landslides in some areas. Although perceived in such terms, it is understood inadequately. It is the universal changes in the behavior of weather patterns based on statistical predictions for a long period of time. It is any long term change in the statistics of weather over periods of time that range from decades to millions of years (IPCC, 2001). These changes are attributed directly or indirectly to the anthropogenic activities which affect sustainability of the biosphere in natural state, thus causing disruptive effects. In East Africa and Sub-Saharan Africa as a whole, there is an 
increase in awareness about climate change even when the initiative to take adaptation and mitigation measures are still low. Surprisingly, as most of the people in the developing world increasingly understand this phenomenon, there is a decline about climate concerns alongside an increase in skepticism regarding its seriousness and anthropogenic causes in the developed countries (Spence, 2011).

The National Aeronautics and Space Administration (NASA) observed that the Earth's 2016 surface temperatures were the warmest since modern record keeping began in 1880, and it may continue over years if no measures are put in place to counteract the effects (Potter, 2016). Due to these climatic variations, people have faced food insecurity as result of crop failure and livestock death. Warming and prolonged droughts in North Eastern Uganda, Kenya, Ethiopia, and Tanzania have caused movements of people across borders searching for water and pastures. This is because of insufficient rainfall which drives them to migrate to new areas (Salerno, 2016). This has created conflicts and insecurity, cattle raids, land degradation, killing of park animals, bush burning in traditionally cattle raiding areas and food insecurity (Ojore, 2017; Okoroafor, 2017; Johnston, 2017; IAWG, 2017) and has put pressure on the natural resource base.

The main objective of this paper therefore, is to suggest possible traditional and nontraditional adaptation and mitigation measures to address food insecurity as a result of climate changes.

\section{Climate change in East Africa and its effects}

East Africa has been hit by climate change leaving millions at the verge of starvation as thousands of livestock die and crops fail due to drought. There is continuous decline in precipitation amounts (Souverijns et al., 2016) as temperatures continuously rise. In many areas of the region, rain-fed agriculture has practically failed. It is estimated that about 11 million people are dangerously food insecure and in need of humanitarian assistance (OXFAM, 2017). Although most areas have been affected by drought, some areas have been affected by floods i.e. Eastern Uganda where over 400 people died due to floods (The International Federation's Disaster Relief Emergency Fund, 2010). Climate change will influence human mobility, resulting in humanitarian crises (Baldwin, 2017). This will create climate migrants or climate refugees and may result into disease outbreak and competition for resources in the recipient areas. Mobility of people with large herds of animals will not only cause conflict but also poor management of animal manure. This will increase greenhouse gases (GHGs). In Ethiopia which has the largest livestock population in Africa (Yohannes, 2016; Amdu, 2010), the large numbers of livestock contribute greatly to emission of GHG. According to a report published by Ethiopian government, $50 \%$ of GHG emissions in the country are attributed to agriculture. Livestock was estimated to have contributed $65 \mathrm{Mt} \mathrm{CO} 2$ equivalent in 2010 (FDRE, 2011).

Agricultural production in the region contributes greatly to the Gross Domestic Product (GDP) and is dominated by smallholder farmers. The adverse climatic effects will affect food production and will substantially reduce the economic base of all the countries in the region. This will affect job creation for the population, majority being the youth, affecting their livelihood. The population growth in the region is among the highest in the world (African Union, 2017) and employment is a big problem and any effect on agricultural production will exacerbate the situation. Furthermore, malnutrition and high mortality in children is likely to increase due to failed agricultural system 
which does not produce sustainably for such a large population. The prices for staple food crops like cereals will rise at the detriment of poor consumers (Karugia et al., 2011).

Climate change will increase human suffering by affecting infrastructure especially in city suburbs as well as agricultural production. This will negatively impact the health of many people (Labbé et al., 2015) and food security respectively.

\section{Materials and methodology}

\section{Profile of the study area}

East Africa is a region that begins in Tanzania in the south and extends north through the great grasslands of Kenya and Uganda and Ethiopia, including the Great Rift Valley (Fig. 1).

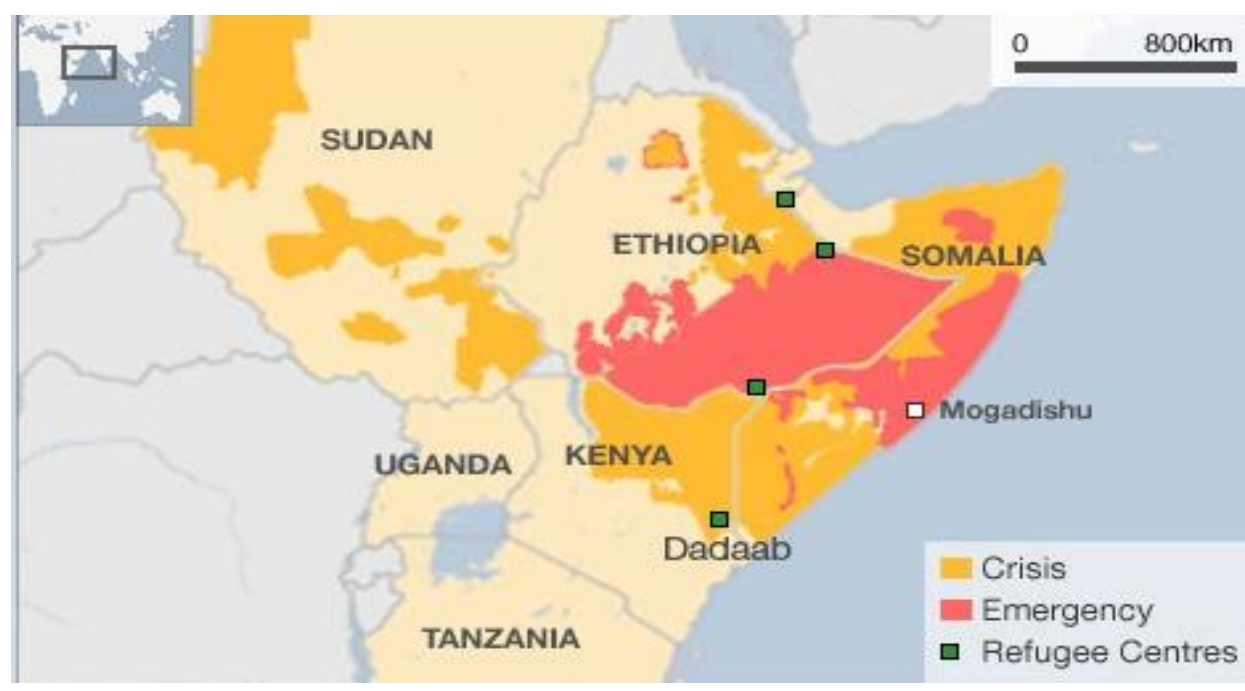

Figure 1. Areas affected by food insecurity and climate change in East Africa. (Source: UNHCR/USAID, 2011)

The region also comprises the countries of South Sudan, Somalia, Djibouti, Eritrea, Rwanda and Burundi.

The world's second-largest lake by surface area is Lake Victoria, which borders Uganda, Tanzania, and Kenya.

In this article, we obtained data from different sources, mostly indexed journals such as Climate change, Environmental Management and other popular sources. UN Organizations such as FAO were also searched to get reports. In our search, we focused on papers that were published in English and are recent 2010-2017. However, some papers were published in 1996, 1999, 2001 and 2005. These were included to highlight on what was previously done and recent work. The terms commonly used in the search strategy were climate change, adaptation, mitigation and food security in East Africa. To manage and screen data well, the articles were grouped into themes and sub-themes. In total, 128 papers were retrieved for possible inclusion from where 52 papers were selected as seen in Table 1. 
Table 1. Summary of the key main articles selected. (Source: Authors)

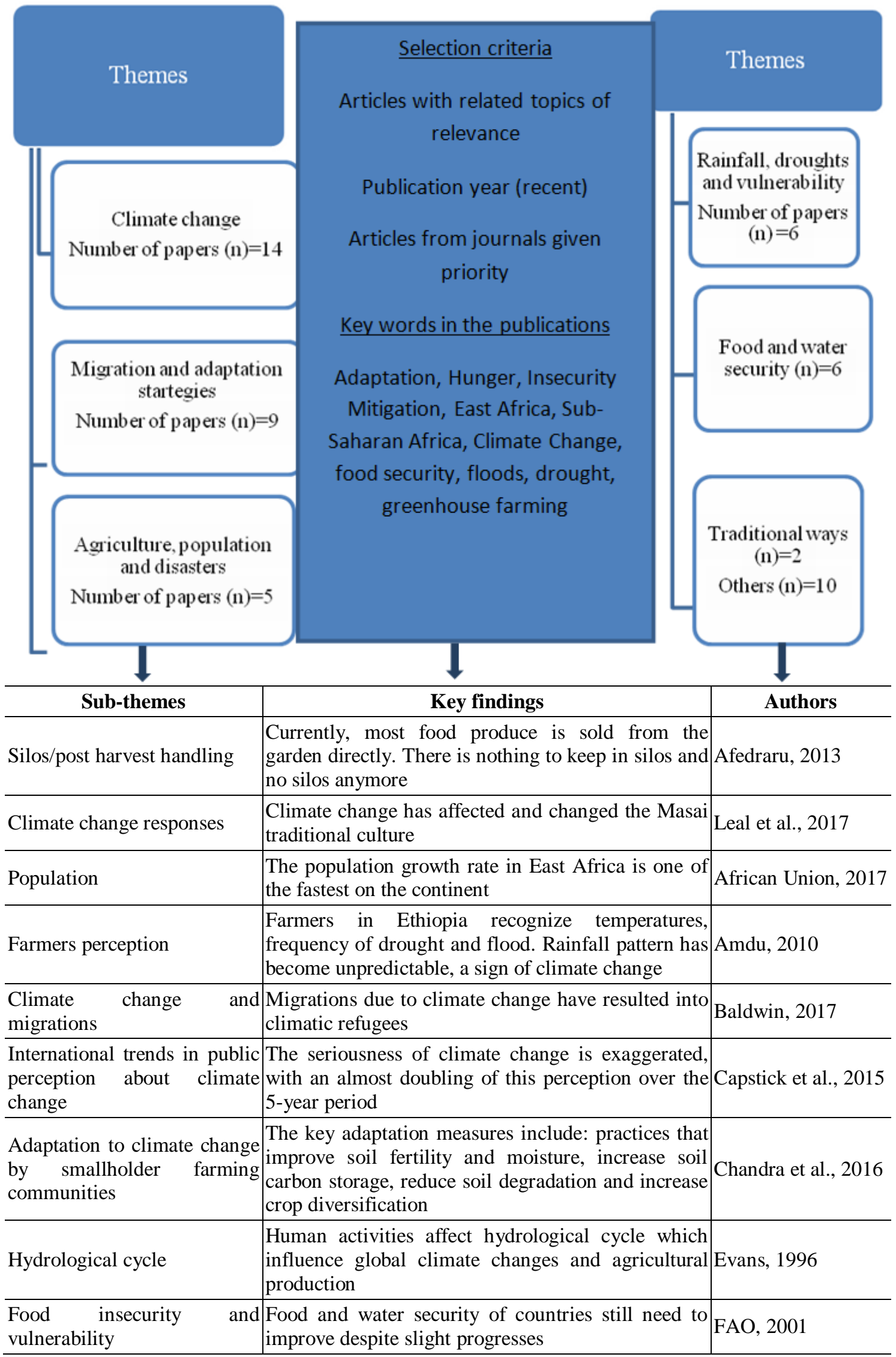




\begin{tabular}{l|l|l|l}
\hline $\begin{array}{l}\text { Climate change, water and } \\
\text { food security }\end{array}$ & $\begin{array}{l}\text { Policy response to climate variability and change } \\
\text { should be flexible and sensible }\end{array}$ & FAO, 2011 \\
\hline Climate-smart agriculture & $\begin{array}{l}\text { Most of the impacts of climate change in agriculture } \\
\text { and rural livelihoods are expected to result from } \\
\text { changes in the water cycle hence rainfall variability }\end{array}$ & FAO, 2013 \\
\hline $\begin{array}{l}\text { Communities and climate } \\
\text { change adaptation }\end{array}$ & $\begin{array}{l}\text { Policies should undergo periodic evaluation to } \\
\text { incorporate traditional knowledge and science } \\
\text { among different communities to adapt to climate } \\
\text { change }\end{array}$ & Ingty, 2017 \\
\hline Agriculture and water & Water harvesting holds a great potential in &
\end{tabular}

management in Uganda, increasing yields and improving food security in FAO, 2016

Burkina Faso and Morocco rain-fed farming areas

\begin{tabular}{|c|c|c|}
\hline Edible insects & $\begin{array}{l}\text { Insect rearing for food remains a sector in its } \\
\text { infancy }\end{array}$ & $\begin{array}{l}\text { FAO Forestry Paper, } \\
2013\end{array}$ \\
\hline $\begin{array}{l}\text { The state of food insecurity in } \\
\text { the world }\end{array}$ & $\begin{array}{l}\text { Prevalence of food insecurity and malnutrition is } \\
\text { significantly higher in protracted crisis contexts } \\
\text { resulting from conflict and natural disasters }\end{array}$ & $\begin{array}{l}\text { FAO, IFAD and } \\
\text { WFP, } 2015\end{array}$ \\
\hline $\begin{array}{l}\text { Ethiopia's climate-resilient } \\
\text { green economy: }\end{array}$ & $\begin{array}{l}\text { Livestock emissions are estimated to be } 65 \mathrm{Mt} \text { CO2e } \\
\text { in } 2010 \text { - more than } 40 \% \text { of total emissions today. } \\
\text { Crop cultivation contributes to concentration of } \\
\text { GHGs by requiring the use of fertilizers }\end{array}$ & $\begin{array}{l}\text { Federal Democratic } \\
\text { Republic of Ethiopia } \\
\text { (FDRE) (2011) }\end{array}$ \\
\hline Hidden hunger & $\begin{array}{l}\text { A new focus must be undertaken to address longer- } \\
\text { term determinants of nutrition insecurity and hidden } \\
\text { hunger }\end{array}$ & $\begin{array}{l}\text { Francesco et al., } \\
2011\end{array}$ \\
\hline Temperature and climate & $\begin{array}{l}\text { Due to increasing climate change, there is a } \\
\text { likelihood of air temperatures exceeding the } \\
\text { optimum range for many species of crops. Cool } \\
\text { season crops will have a constrained growing season } \\
\text { due to high temperatures }\end{array}$ & $\begin{array}{l}\text { Hatfield } \\
\text { Prueger, } 2015\end{array}$ \\
\hline Drought crisis & $\begin{array}{l}\text { More than } 15 \text { million people in Ethiopia, Kenya and } \\
\text { Somalia are facing food and water shortages }\end{array}$ & IAWG, 2017 \\
\hline Adaptation and vulnerability & $\begin{array}{l}\text { Developing countries, particularly the least } \\
\text { developed countries, have lesser capacity } \\
\text { to adapt than do developed countries }\end{array}$ & IPCC, 2001 \\
\hline Encroachment of wetlands & $\begin{array}{l}\text { Multi-faceted approach, coordination of the various } \\
\text { stakeholders and engagement of wetland-dependent } \\
\text { communities as part of the solution, might require } \\
\text { zoning out the wetland and restricting certain } \\
\text { activities to specific zones }\end{array}$ & Isur \\
\hline Tackling climate change & $\begin{array}{l}\text { Without global efforts to reduce emissions and to } \\
\text { help the world's poorest people cope with the effects } \\
\text { of climate change, this crisis will continue to repeat } \\
\text { itself }\end{array}$ & Johnston, 2017 \\
\hline Food prices & $\begin{array}{l}\text { The prices for staple food crops like cereals will rise } \\
\text { at the detriment of poor consumers }\end{array}$ & Karugia, 2011 \\
\hline $\begin{array}{l}\text { Adaptation to climate risks in } \\
\text { East Africa }\end{array}$ & $\begin{array}{l}\text { Adoption of adapted varieties of crops might be } \\
\text { successful to enhancing resilience of farming } \\
\text { systems in the short-term }\end{array}$ & Kelvin, 2017 \\
\hline $\begin{array}{l}\text { Beekeeping as integrated } \\
\text { watershed conservation and } \\
\text { climatic change adaptation }\end{array}$ & $\begin{array}{l}\text { Beekeeping is an environmentally sound, and } \\
\text { economically feasible income generating activity for } \\
\text { poverty alleviation and food security }\end{array}$ & $\begin{array}{l}\text { Kumsa and Gorfu, } \\
2014\end{array}$ \\
\hline
\end{tabular}




\begin{tabular}{|c|c|c|}
\hline $\begin{array}{l}\text { Vulnerability to the health } \\
\text { effects of climate variability, } \\
\text { Uganda }\end{array}$ & $\begin{array}{l}\text { Vulnerability to the health impacts of climate } \\
\text { change will be shaped by existing burdens of ill- } \\
\text { health, climate-sensitive infrastructures, limited } \\
\text { technological capacity and political inequality and is } \\
\text { expected to be highest in socioeconomically } \\
\text { marginalized populations }\end{array}$ & Labbé et al., 2015 \\
\hline $\begin{array}{l}\text { Achieving mitigation and } \\
\text { adaptation to climate change }\end{array}$ & $\begin{array}{l}\text { Agroforestry systems readily bundle both mitigation } \\
\text { and adaptation strategies and provide several } \\
\text { pathways to securing food security for poor farmers, } \\
\text { while contributing to climate change mitigation }\end{array}$ & Mbow et al., 2013 \\
\hline $\begin{array}{l}\text { Vulnerability to climate } \\
\text { change }\end{array}$ & $\begin{array}{l}\text { Higher standards of living in Tibet have enabled } \\
\text { herders to deploy the coping strategies of sheltering } \\
\text { livestock and feeding them supplements }\end{array}$ & Yeh et al., 2014 \\
\hline $\begin{array}{l}\text { water availability in a } \\
\text { changing climate }\end{array}$ & $\begin{array}{l}\text { Changing rainfall patterns affect seasonal } \\
\text { availability and manageability of water }\end{array}$ & Milly, 2005 \\
\hline $\begin{array}{l}\text { Migration as an adaptation } \\
\text { measure }\end{array}$ & $\begin{array}{l}\text { A model to predict future climate change-migration } \\
\text { relationships developed }\end{array}$ & $\begin{array}{l}\text { MCLeman } \\
\text { Smit, } 2006\end{array}$ \\
\hline $\begin{array}{l}\text { Food relief in North East } \\
\text { Uganda }\end{array}$ & $\begin{array}{l}\text { Elderly and children affected by drought. } 80 \text { people } \\
\text { died because of lack of food in } 2 \text { counties }\end{array}$ & Ojore, 2017 \\
\hline Drought in East Africa & $\begin{array}{l}\text { Thousands of animals including cows, goats, and } \\
\text { sheep have already been lost }\end{array}$ & Okoroafor, 2017 \\
\hline $\begin{array}{l}\text { climate change and drought } \\
\text { in East Africa }\end{array}$ & $\begin{array}{l}\text { Nearly eleven million people in Kenya, Ethiopia and } \\
\text { Somalia are dangerously hungry and in need of } \\
\text { humanitarian aid }\end{array}$ & $\mathrm{OX}$ \\
\hline Temperature rise & $\begin{array}{l}\text { Earth's } 2016 \text { surface temperatures were the warmest } \\
\text { since modern record keeping began in } 1880\end{array}$ & Potter, 2016 \\
\hline $\begin{array}{l}\text { Neglected and underutilized } \\
\text { crop }\end{array}$ & $\begin{array}{l}\text { Key to future food and nutrition security may very } \\
\text { well lie in the untapped potential of neglected and } \\
\text { underutilized crops }\end{array}$ & Pau \\
\hline Rainfall distribution patterns & $\begin{array}{l}\text { Reduced interannual variability occurred, the } \\
\text { percentage of dry years did not increase but the } \\
\text { percentage of wet and very wet years decreased }\end{array}$ & 2001 \\
\hline $\begin{array}{l}\text { Indigenous knowledge related } \\
\text { to climate variability }\end{array}$ & $\begin{array}{l}\text { The rich indigenous knowledge can be combined } \\
\text { with science to monitor climate change }\end{array}$ & Speranza et al., 2017 \\
\hline $\begin{array}{l}\text { Food security and seasonal } \\
\text { climate }\end{array}$ & $\begin{array}{l}\text { Extreme climate events, such as droughts and } \\
\text { floods, and lower agricultural productivity } \\
\text { contribute to food insecurity }\end{array}$ & $\begin{array}{l}\text { Rarieya and Fortun, } \\
2010\end{array}$ \\
\hline $\begin{array}{lrr}\text { Managing } & \text { vulnerability to } \\
\text { drought } & \text { and } & \text { enhancing } \\
\text { livelihood } & \text { resilience: } \\
\text { Technological, institutional } \\
\text { and policy option }\end{array}$ & $\begin{array}{l}\text { Drought represents one of the most important } \\
\text { natural factors contributing to malnutrition and } \\
\text { famine that affects the most vulnerable } \\
\text { communities, especially women, children and the } \\
\text { elderly }\end{array}$ & Shiferaw et al., 20 \\
\hline East African precipitation & $\begin{array}{l}\text { Precipitation amounts over East Africa have been } \\
\text { declining over the last decades }\end{array}$ & Souverijns, 2016 \\
\hline Perceptions of climate change & $\begin{array}{l}\text { There is a decline about climate concerns alongside } \\
\text { an increase in skepticism regarding its seriousness } \\
\text { and anthropogenic causes in the developed countries }\end{array}$ & Spence, 2011 \\
\hline Africa's hidden hunger & Many families in East Africa, eat one meal in a day & Stefan, 2012 \\
\hline $\begin{array}{l}\text { Attribution of extreme } \\
\text { weather and climate }\end{array}$ & $\begin{array}{l}\text { Climate models show an increased occurrence of } \\
\text { extreme temperature and rainfall events worldwide } \\
\text { which are attributed to anthropogenic activities }\end{array}$ & et al., 2016 \\
\hline
\end{tabular}




\begin{tabular}{|c|c|c|}
\hline Floods and landslides & $\begin{array}{l}\text { An estimated } 400 \text { people were killed by floods and } \\
\text { landslides in Eastern Uganda }\end{array}$ & DREF, 2010 \\
\hline $\begin{array}{l}\text { Lake Victoria ecological } \\
\text { changes }\end{array}$ & $\begin{array}{l}\text { Decline in fish species is the highest documented } \\
\text { loss of biodiversity caused by humans in an } \\
\text { ecosystem }\end{array}$ & Witte \\
\hline $\begin{array}{l}\text { Climate change } \\
\text { agriculture }\end{array}$ & $\begin{array}{l}\text { Climate change has relationship with agriculture in } \\
\text { one or another way }\end{array}$ & Yohannes, 2016 \\
\hline $\begin{array}{l}\text { Climate variability-farmers } \\
\text { perception, Kenya }\end{array}$ & $\begin{array}{l}\text { Farmers are aware of climate changes because of } \\
\text { decrease in rainfall amount, rainfall variability, } \\
\text { erratic rains and prolonged drought periods }\end{array}$ & Gic \\
\hline $\begin{array}{l}\text { Adapting agriculture } \\
\text { climate change-Kenya }\end{array}$ & $\begin{array}{l}\text { Households face considerable challenges in adapting } \\
\text { to climate change, need for greater investments to } \\
\text { support households to make strategic, long-term } \\
\text { decisions }\end{array}$ & Bry \\
\hline $\begin{array}{l}\text { Migrations and decision } \\
\text { making }\end{array}$ & $\begin{array}{l}\text { Insufficient rainfall drives agro pastoralists to } \\
\text { migrate to new areas }\end{array}$ & Salerno, 2016 \\
\hline $\begin{array}{l}\text { Climate change } \\
\text { environmental threats }\end{array}$ & $\begin{array}{l}\text { Increased evaporation rates, will increase levels of } \\
\text { salinity in the lake, harm fish stocks worsening food } \\
\text { security situation }\end{array}$ & $\begin{array}{l}\text { Human Rights } \\
\text { Watch, } 2015\end{array}$ \\
\hline $\begin{array}{l}\text { Drought tolerant maize for } \\
\text { farmer adaptation }\end{array}$ & $\begin{array}{l}\text { Major barriers to crop adoption is unavailability of } \\
\text { seeds }\end{array}$ & Fisl \\
\hline $\begin{array}{l}\text { African indigenous cattle: } \\
\text { Unique genetic resources }\end{array}$ & $\begin{array}{l}\text { African livestock genetic resources are in danger } \\
\text { due to uncontrolled crossbreeding }\end{array}$ & Mwai, 2015 \\
\hline
\end{tabular}

\section{Results}

From Table 1, six themes have been developed to summarize information published and give suggestions on mitigation and adaptation strategies.

\section{Anthropogenic activities contributing to climate change in East Africa}

Anthropogenic activities have caused challenges to mankind (Stott et al., 2016) by greatly contributing to climate change. There is a growing trend in awareness about this in some parts of the world including East Africa although in other areas, there is a decline in knowledge by the public about climate change being caused by human actions (Capstick et al., 2015).

Activities such as forest clearing for charcoal, bush burning as a way of facilitating growth of fresh grass for animals and swamp destruction for agriculture contribute greatly to climate change. They negatively influence biogeochemical cycles of evapotranspiration, hydrological cycles, rainfall distribution and amount, increase flood and drought frequencies (Evans, 1996; Ramos, 2001).

\section{Industrial and agricultural development}

Climate change with reduced precipitation levels has characterized most of the areas in East Africa. Over the past several years, Ethiopia has embarked on a massive plan for dams, water-intensive irrigated cotton, sugar plantations, irrigation canals and other infrastructural developments in the Omo River Basin. Predictions indicate that these developments could have a devastating impact on water bodies particularly Lake Turkana, dropping water levels and potentially causing the lake to recede into two small pools. If these predictions are accurate, areas of Lake Turkana with high levels of 
biological productivity that are critical for fish breeding will dry up causing significant effects on fisheries. In addition, dramatic reductions in freshwater from the Omo River into Lake Turkana, will increase salinity and temperature in the lake. This will harm fish stocks worsening the already dire food security situation in the region and affecting the lives of many people (Human Rights Watch, 2015).

In Figure $2 a$, eucalyptus trees were planted by a tea factory in what used to be a wetland, to be used for firewood as a form energy in tea processing and it has drained the water leaving the land dry while in Figure $2 e$, the water level and quantity has dropped substantially due to drainage and destruction of the vegetation. Most ecosystems in Uganda and East Africa as a whole have been destroyed and this hinders carbon sequestration processes, increasing greenhouse gases (GHGs).

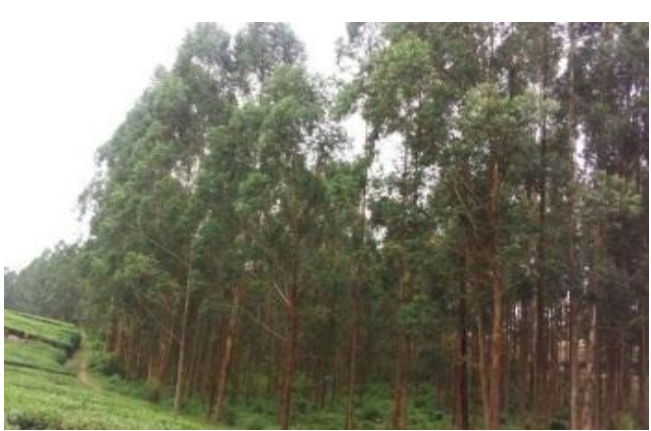

$\mathbf{a}$

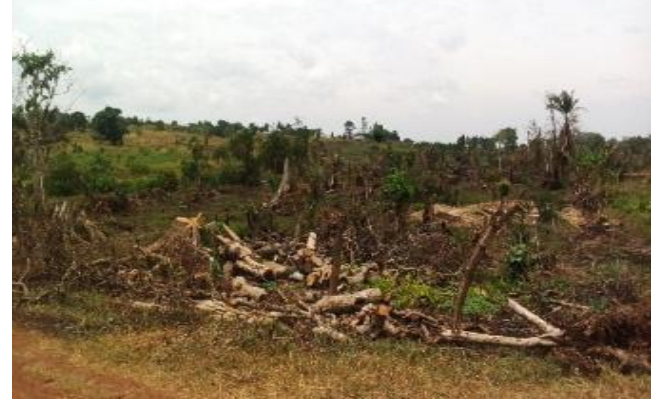

c

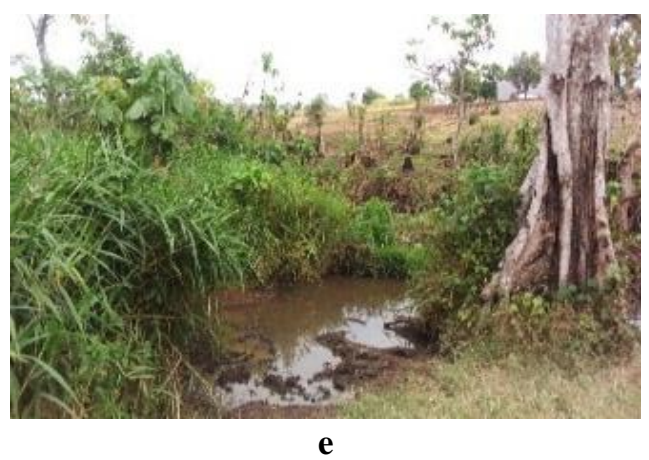

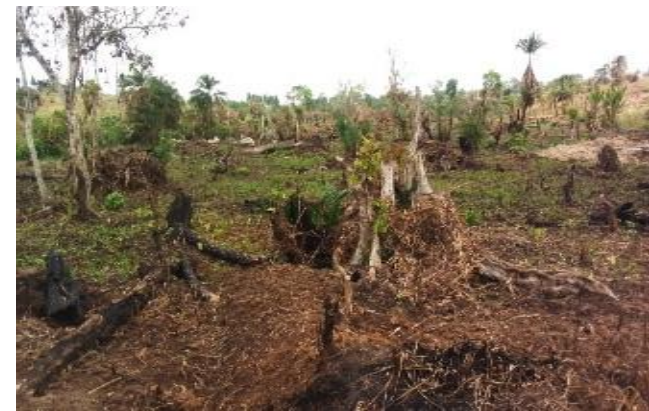

b

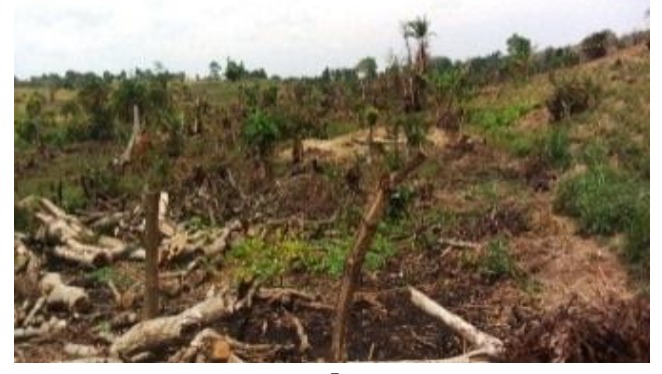

d

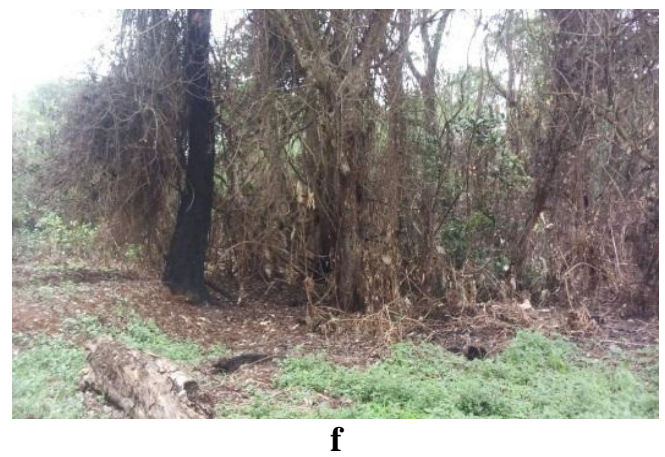

Figure 2. A destroyed ecosystem in Hoima District, Uganda. (Source: Authors)

\section{Food and water security in East Africa due to climate change}

Food and water are inseparable and are useful for sustenance of life. They influence the quality of life people have. Despite having significant land and water resources, East Africa is one of the world's most food-insecure regions. There is water stress despite the 
presence of rivers and lakes. River Nile, Lake Victoria, Lake Tanganyika and Lake Turkana are some of the important water bodies in the region. Current management of these water resources needs improvement as a result of exploitation of fishery resources and pollution of water ecosystems by industrial and agricultural activities. The Nile basin which covers the biggest area in the region is an example of a drainage system that would shock absorb the adverse effects of climate change if managed sustainably by all countries in the Nile Basin Initiative. The technology to draw water for various agricultural operations is still undeveloped. Agro-pastoral groups move across borders instead of tapping such water that is near them. Changing rainfall patterns affect seasonal availability and manageability of water, and by 2070, there will be less water in East Africa and other parts of the world (Milly et al., 2005; FAO, 2011).

More so, the water level in Lake Victoria has dropped and warmed. The surface water has warmed by almost $1.2^{\circ} \mathrm{C}$ in 82 years, and the temperature has risen by $1.6^{\circ} \mathrm{C}$ in water greater than $50 \mathrm{~m}$ deep over the same time period (FAO, 2016). Whereas global climatic changes may have primarily contributed to these changes, anthropogenic activities like forest and swamp destruction cannot be underestimated. High temperatures will impact fisheries productivity by lowering the quantity and size of fish but may affect water ecology as well. The warm temperatures lead to faster depletion of the limited oxygen supply, negatively impacting fish development. The impact of climate change on commercial fishing in East Africa's water bodies is uncertain, and reductions in water levels and the impacts of extreme climate events resulting from climate change are likely to have significant negative effects on the water bodies. Decline in fish species in Lake Victoria is the highest documented loss of biodiversity caused by humans in an ecosystem (Witte, 1999). This is a big concern as fish is an important source of protein and income to many people.

According to the Food and Agriculture Organization of the United Nations (2001) "Food security is a situation that exists when all people, at all times, have physical, social and economic access to sufficient, safe and nutritious food that meets their dietary needs and food preferences for an active and healthy life". This means that food should be available, accessible, utilizable and stable. The current food situation in East Africa cannot make it possible for most households to have enough, nutritious and even have preference of certain foods to others. The food insecurity problem is compounded by climatic changes of drought and floods which affect agricultural production in many ways (Rarieya and Fortun, 2010).

Besides, there is another problem of "hidden hunger" that affects many communities. This is caused by low intake of vitamins from vegetables. This is a serious public health concern affecting many families in East African countries (Stefan, 2012). Surprisingly, it is not understood well and for that reason, most people are not aware about it (Francesco et al., 2011). Climate change is a complex global problem involving food constraints, water scarcity even in abundance, movements of people, climate health related illnesses and above all occurrence of unpredictable disasters (Table 2).

Low developed countries are the most affected, particularly Sub-Saharan Africa and South-Eastern Asia. People line up early in the morning hours to collect water in some areas in Uganda (Fig. 3a) while in Figure 3b, women and children trek long distance to get water from a river whose depth has also been reducing due to a long dry spell.

The situation is worse in conflict stricken areas like Somalia where there are internally displaced people (Figure 3c). The dwindling water levels in surface water and other water sources is related to anthropogenic activities. 
Table 2. Undernourishment in different parts of the world, emphasis on East Africa. (Source: Adapted from FAO, IFAD and WFP, 2015)

\begin{tabular}{c|c|c|c|c|c|c}
\hline & \multicolumn{2}{|c|}{$\mathbf{2 0 0 5 - 0 7}$} & \multicolumn{2}{c|}{$\mathbf{2 0 1 0 - 1 2}$} & \multicolumn{2}{c}{$\mathbf{2 0 1 4 - 2 0 1 6}$} \\
\cline { 2 - 7 } & No. & $\mathbf{\%}$ & No. & $\mathbf{\%}$ & No & $\mathbf{\%}$ \\
\hline WORLD & 942.3 & 14.3 & 820.7 & 11.8 & 794.6 & 10.9 \\
Developed regions & 15.4 & $<5.0$ & 15.7 & $<5.0$ & 14.7 & $<5.0$ \\
Developing regions & 926.9 & 17.3 & 805.0 & 14.1 & 779.9 & 12.9 \\
Africa & 213.0 & 22.7 & 218.5 & 20.7 & 232.5 & 20.0 \\
Northern Africa & 7.0 & $<5.0$ & 5.1 & $<5.0$ & 4.3 & $<5.0$ \\
Sub-Saharan Africa & 206.0 & 26.5 & 205.7 & 24.1 & 220.0 & 23.2 \\
Eastern Africa & 122.5 & 37.8 & 118.7 & 33.7 & 124.2 & 31.5 \\
Middle Africa & 47.7 & 43.0 & 53.0 & 41.5 & 58.9 & 41.3 \\
Southern Africa & 3.5 & 6.2 & 3.6 & 6.1 & 3.2 & 5.2 \\
Western Africa & 32.3 & 11.8 & 30.4 & 9.7 & 33.7 & 9.6 \\
Asia & 665.5 & 17.3 & 546.9 & 13.5 & 511.7 & 12.1 \\
Caucasus and Central Asia & 8.4 & 11.3 & 7.1 & 8.9 & 5.8 & 7.0 \\
Eastern Asia & 217.6 & 15.2 & 174.7 & 11.8 & 145.1 & 9.6 \\
South-Eastern Asia & 319.1 & 20.1 & 274.2 & 16.1 & 281.4 & 15.7 \\
Southern Asia & 319.1 & 20.1 & 274.2 & 16.1 & 281.4 & 15.7 \\
Western Asia & 17.2 & 9.3 & 18.4 & 8.8 & 18.9 & 8.4 \\
Catin America and the Caribbean & 47.1 & 8.4 & 38.3 & 6.4 & 34.3 & 5.5 \\
Caribbean & 8.3 & 23.5 & 7.3 & 19.8 & 7.5 & 19.8 \\
Latin America & 38.8 & 7.3 & 31.0 & 5.5 & 26.8 & $<5.0$ \\
Central America & 11.6 & 7.6 & 11.3 & 6.9 & 11.4 & 6.6 \\
South America & 27.2 & 7.2 & ns & $<5.0$ & ns & $<5.0$ \\
Oceania & 1.3 & 15.4 & 1.3 & 13.5 & 1.4 & 14.2 \\
\hline
\end{tabular}

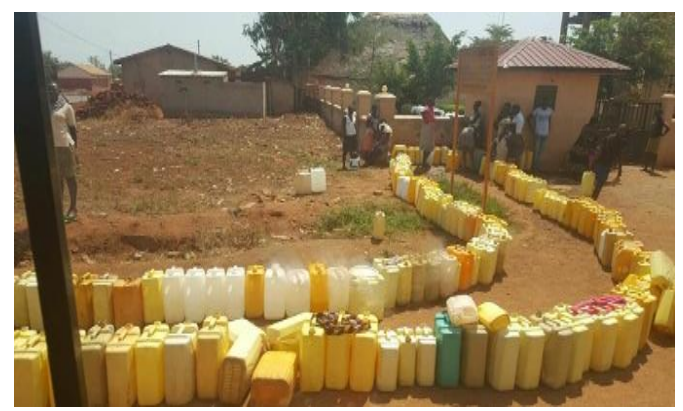

$\mathbf{a}$

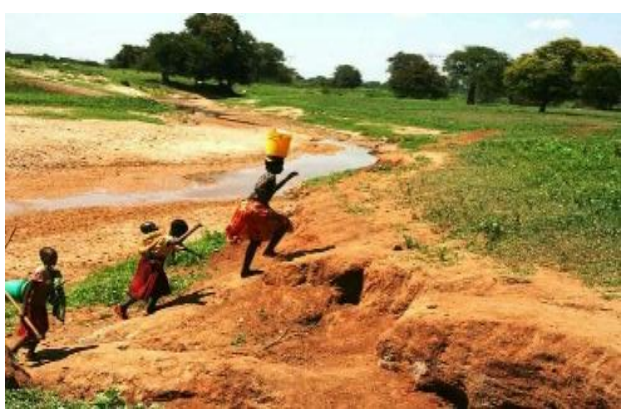

b

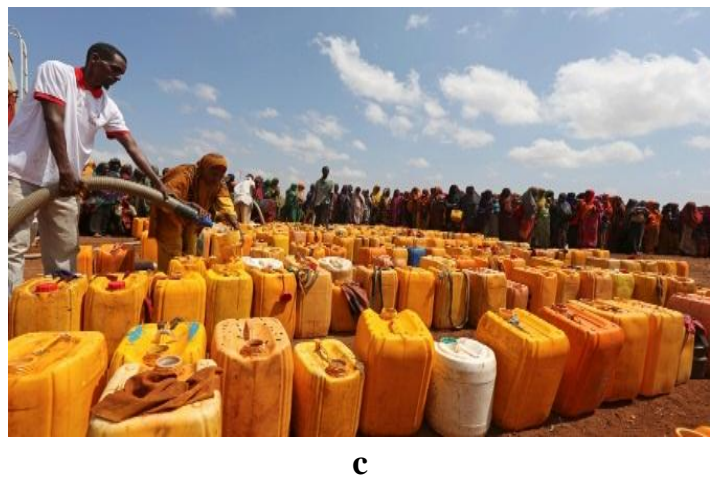

Figure 3. Water shortages in different areas of East Africa. (Source: Authors) 
Food security and water access in the region remain one of the serious development bottlenecks that impact other key sectors and have led to dismal realization of sustainable development goals.

\section{Misuse of natural resources}

In many ways, water, wetlands have either been diverted, drained in expansion of cities or polluted and degraded with permanent horticultural facilities such as greenhouse facilities which discharge effluent (Entebbe in Uganda) and Kisumu in Kenya all located on the shore of Lake Victoria. These activities affect water quantity and quality. When water is displaced from its natural watershed where it sustains healthy ecosystem, due to diversion or expansion of towns, natural hydrological cycle is affected. Agrochemical pollutants from the greenhouse flower farms end up in surface water causing eutrophication. This affects fisheries development. It also creates a need to search for ground water using boreholes which reduce the water cycle. Urbanization, deforestation and wetland destruction greatly destroy water-retentive landscapes and lead to the loss of precipitation over the affected area. If there are no trees to receive the rain, it will evaporate, creating desert-like conditions. An example is Kampala, Uganda's capital city, where Nakivubo wetland covered by natural vegetation has reduced by approximately $14 \%$ in 5 years while cultivated area in the lower Nakivubo wetland had increased by more than $350 \%$ in the same period. (Isunju, 2016).

In Figure $4 a$, a bulldozer clears the area for a flower farm in Lutembe, EntebbeUganda. The area, deemed to be of international importance under an international convention on wetlands was destroyed to set up a flower farm on a bay off the shores of Lake Victoria. In Figure 4b, buildings have been constructed there and the wetland is no more while in Figure $4 c$, the residents of Ndemi, Michore, Kieni and Rukuma, destroy pipes that are used to draw water from river Malewa by Mahee Flower farm in Kenya. The residents accuse Mahee Flowers farms of polluting the water with chemical effluents and blocking water movement.

\section{Discussion}

As seen in Table 1, a number of researches have been done about climate change and people in the region are aware of the problem. Climate change theme is a dominant topic that is discussed and covered in most researches. It is however evident in most papers and reports that the issue of traditional measures and technologies to address food insecurity have not been emphasized in mitigating effect. Most publications have tackled on causes and implications of the problem. It is important that research on nontraditional technologies and modern technologies be emphasized (Fig. 5) and if possible be improved for the sake of resource constrained people who are the majority in the region. This can promote sustainable and inclusive development. Policies that encourage farmers and emphasize the re-establishment of such structures should be implemented.

Furthermore, the problem of food insecurity is exacerbated by some farmers who sell food from the garden directly, Table 1. This could be due to economic hardships faced by the people, and a weak government policy that does not enforce keeping food in silos to prepare for disasters like droughts. The issue of food security and climate change seem to be intertwined that it is almost impossible to talk about one while leaving the other. 

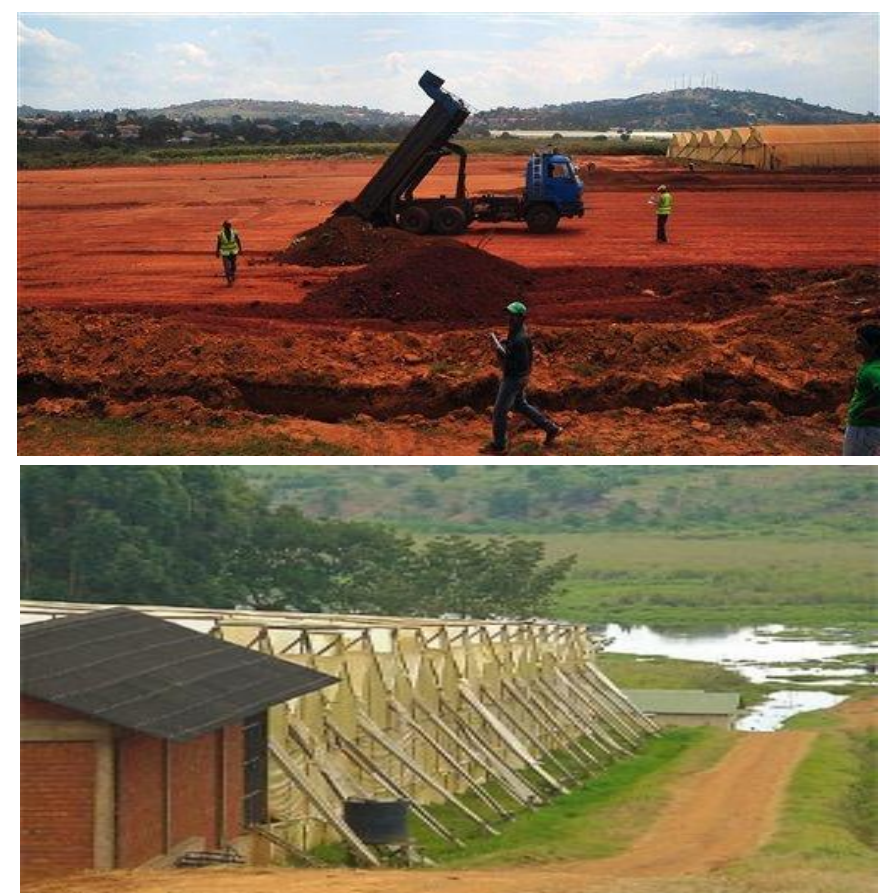

$\mathbf{a}$
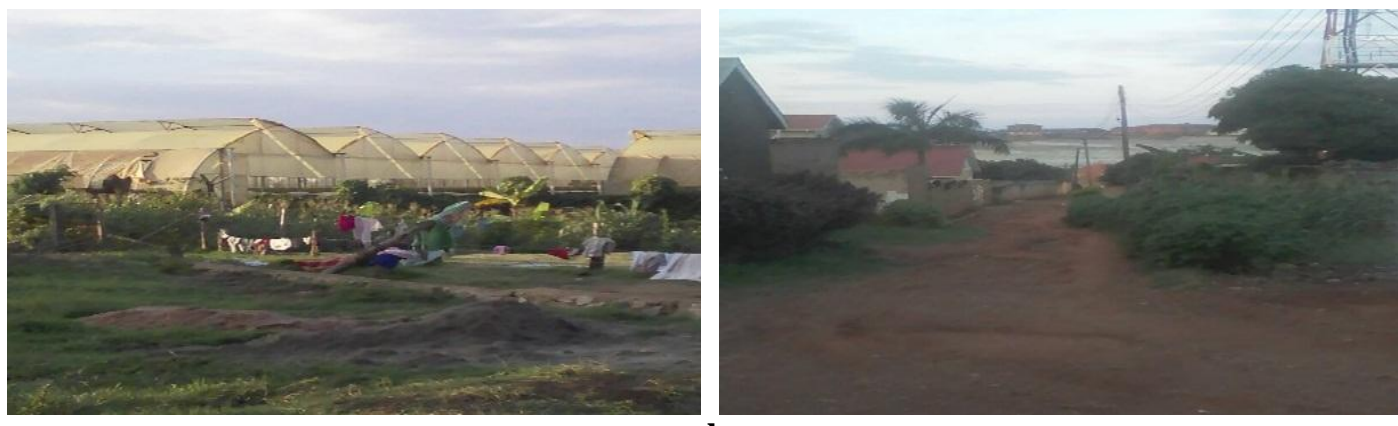

b

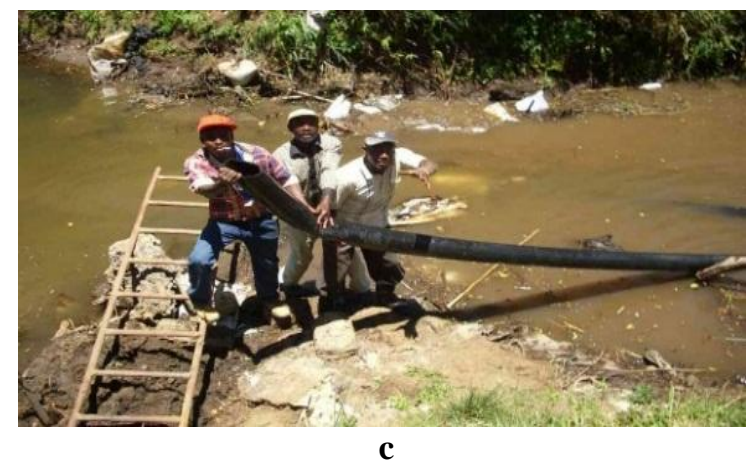

Figure 4. Destruction of wetland and river ecosystems in Uganda and Kenya. (Source: Authors)

The destruction of ecosystem for agricultural activities, urban development is one of the reasons that partly explain why climatic disasters continue to affect East Africa. Many fragile ecosystems have been damaged in most areas (Figs. 2 and 4). Most agricultural activities take place in areas that act as buffers for carbon sequestration i.e. wetlands and forests. When these are destroyed, there is a disturbance in carbon dioxide flux management, hydrological cycles and species extinction that are interlinked in a complex manner. This situation is intensified by grazing huge numbers of livestock that 
move within countries and across the region as is it the case with almost all pastoral groups in East Africa (Karamajong of Uganda, Turkana of Kenya, Masai of Tanzania and the Ethiopians). This causes soil erosion due to vegetation loss and emission of GHGs, thus global warming. The phenomenon is more complex with other problems of wars in South Sudan, Somalia and general political instabilities in the region which contribute to food insecurity.

It is evident that the number one climatic disaster affecting East Africa is drought (Table 3). It causes more misery than all the other disasters combined and is more recurrent. This increasing trend and frequency in drought is a sign of degenerating environmental problem that is brought about by climate change induced by anthropogenic activities. The frequency of droughts is higher than that of any other climatic disaster. This explains the movements of pastoral groups across borders where they end up fighting with the local people hence increasing insecurity.

Table 3. People affected by climatic disasters in Uganda, East Africa, since 1979. (Source: Adjusted from Climate Policy Paper, 2012)

\begin{tabular}{c|c|c}
\hline Year & Population & Disaster \\
\hline 1979 & 500000 & Drought \\
1987 & 600000 & Drought \\
1997 & 153500 & Floods \\
1997 & 100000 & Epidemic \\
1998 & 126000 & Drought \\
1999 & 700000 & Drought \\
2001 & 655000 & Drought \\
2005 & 600000 & Drought \\
2007 & 718045 & Floods \\
2008 & 11000000 & Drought \\
2010 & 338 & Landslides \\
2013 & 500000 & Drought \\
\hline
\end{tabular}

\section{Hunger and "hidden hunger"}

Pregnant women, children and elderly need vegetables regularly. Unfortunately, most of indigenous vegetables are at the verge of extinction in most communities, especially in war torn areas of South Sudan and Somalia. This is because of inadequate conservation measures and insecurity. Those vegetables used to be grown in back yard gardens but in recent times, people live in urban areas and cannot access them. East Africa remains the sub-region with the biggest hunger problem, with over $31 \%$ undernourished people (FAO, IFAD, WFP, 2015). This phenomenon is further complicated by inadequate clean water supply in most of the rural areas and some areas in urban centers of East Africa (Fig. 3).

\section{Suggested mitigation and adaptation measures to guard against food insecurity}

\section{Traditional strategies}

Traditional ways of guarding against food insecurity in East African communities were very important in preparing people for any future disaster that could occur. These 
technologies were cheap and did not need any expertise to harness. In most communities however, these simple technologies phased out. Therefore, communities and policy makers should do the following:

\section{Revive use of silos}

Most areas in East Africa used to have silos controlled by government at sub-county level where farmers would collectively store food but also, individual families owned silos for grains (Afedraru, 2013). They played a crucial role in periods of bumper harvests to store what the markets could not absorb at reasonable prices. This practice worked well to safeguard families from future risks of climatic disasters. On the contrary, most of the farmers in most communities nowadays, have no silos and sometimes sell their food crops even when it is still in the garden risking the lives of their members in case of food shortage. The few government silos that are still in existence are empty and in a very bad state. This has been noticed in recent times when most communities in the region, particularly Uganda, have been affected by various disasters, especially drought.

Traditional silos (Fig. 5a) are very few and even where they exist, they have no grains to store. Modern silos (hermetic) (Fig. 5b) are being promoted by WFP in some parts of East Africa. Improvised greenhouses (Fig. 5c) can be useful to resource constrained farmers while commercial farmers can use semi-automated greenhouses (Fig. 5d) to address food insecurity and erratic weather. In mitigating impact of climate change on food security, silos are not an option but a requirement (Afedraru, 2013).

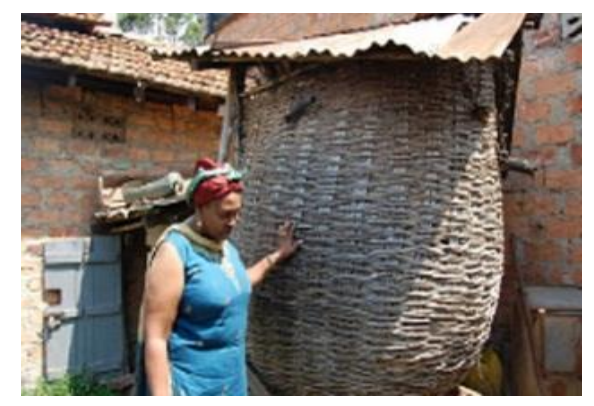

$\mathbf{a}$

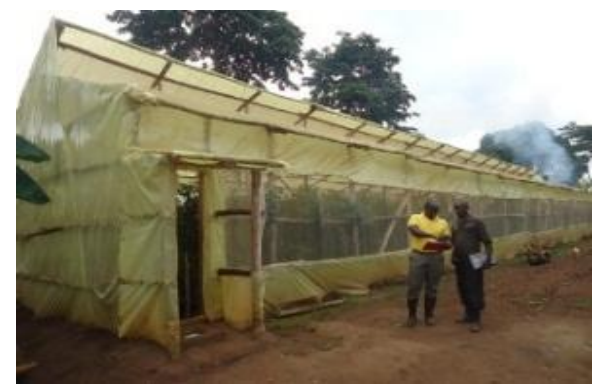

c

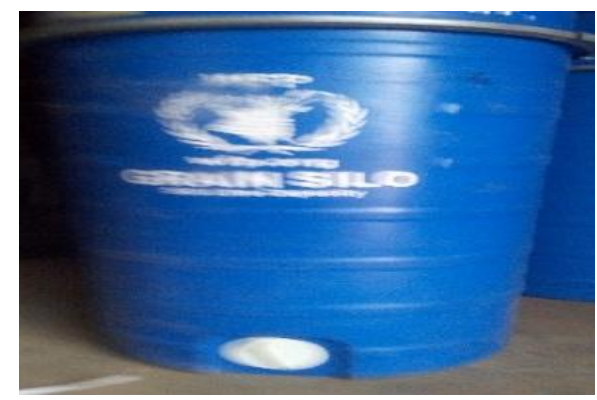

b

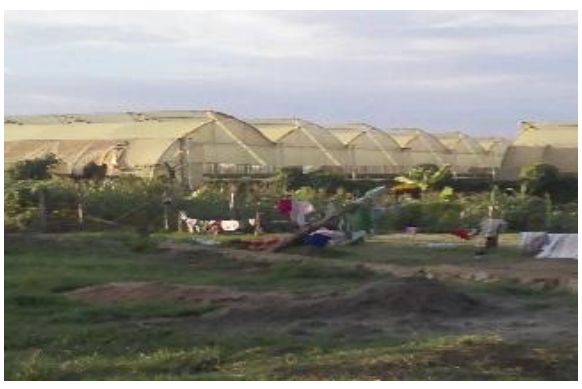

d

Figure 5. Technologies that need promotion and adoption. (Source: Authors) 


\section{Growing indigenous vegetables}

This can address the problem of "hidden hunger". Most of the homesteads in East Africa used to have these vegetables in backyard gardens. They are unique and well adopted to the local conditions. They can reduce GHG emissions which come from heavy use of fertilizers and pesticides used in growing introduced varieties. They respond well to organic soil amendment, can grow reasonably well in water scarce conditions (Pauline et al., 2015) and are resilient to climate change (Fig. 6).

Most of these vegetables are rich in vitamins. However, most farmers have opted to grow the hybrid varieties because of economic gains leaving indigenous species at the verge of extinction.

a
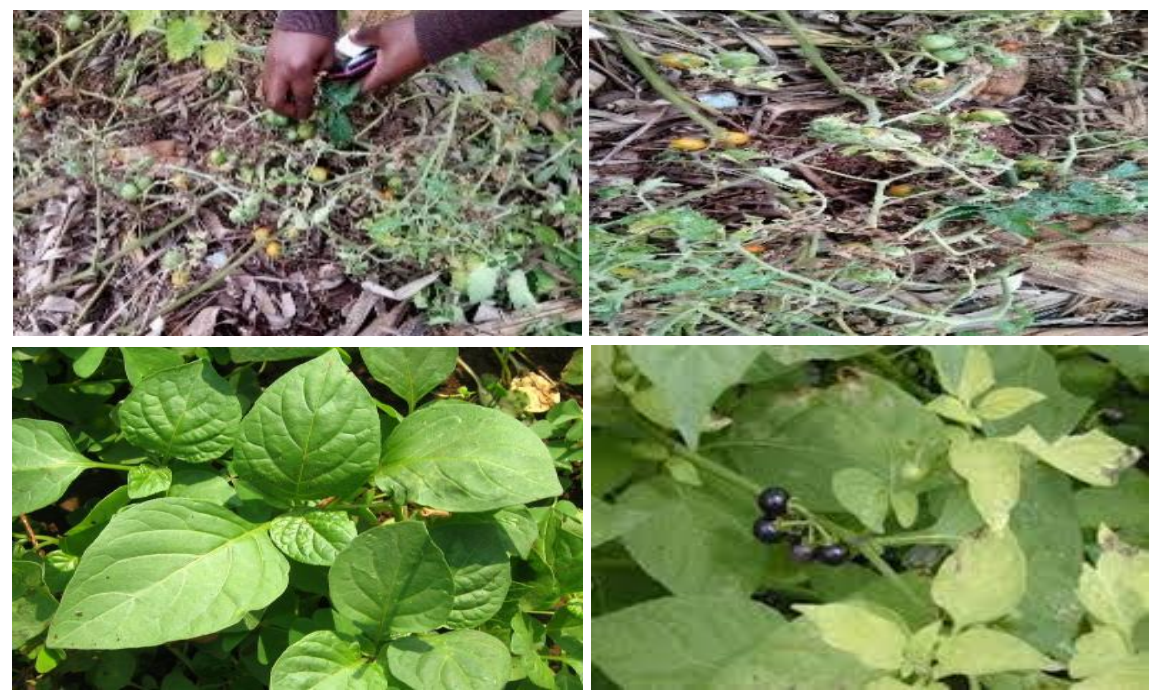

b
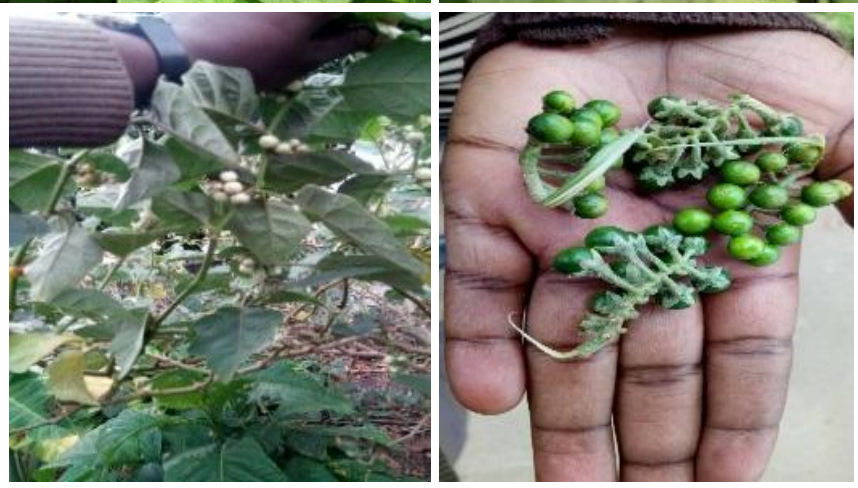

Figure 6. Indigenous vegetables at the verge of extinction in East Africa (a) Lycoperscum esculentum (b) African night shade (c) Solanum anguivi. (Source: Authors)

\section{Apiary projects}

Combined with agroforestry, it is possible to run these profitable enterprises. In a situation where food is scarce, honey can be a good source of carbohydrates, medicine and source of income. Beekeeping is an environmentally sound, technically suitable and economically feasible income generating activity for poverty alleviation and food security (Kumsa and Gorfu, 2014). Beekeeping could be one of the major sources of income, food for people in local communities that are struggling with climate change. 


\section{Non-traditional strategies}

Non-traditional measures are modern ways, services and technologies that can enhance resilience of communities to effects of climate change in enhancing food security. They are more expensive compared to non-traditional measures and require expertise.

\section{Insurance}

With climate change continuing to ravage the region, farmers need viable and affordable ways to manage these weather-related risks which threaten food security and economic stability. Most farmers in East Africa lack access to insurance services.

\section{Greenhouse farming}

Farmers need to adopt the use of this technology to grow crops. It has many advantages i.e. growing of crops throughout the year, easy management of pests and diseases and efficient water use. Although there are challenges with this type of farming like the cost of the technology, especially to smallholder, financially constrained farmers, there are many benefits if well maintained. Governments needs to draft policies on how to help farmers access these important agricultural technologies cheaply and where possible, establish agricultural financing mechanisms to enable resource constrained but knowledge equipped farmers to have them.

\section{Other strategies}

\section{Acceptance of new foods}

In some areas of East Africa, certain foods like insects and worms are not eaten due to negative perceptions yet they are a good source of protein just like fish, chicken and meat. If promoted as food, insects emit fewer GHGs (FAO Forestry Paper, 2013) than livestock. There are diverse types of insects that can play nutritional roles and they are easy to farm compared to traditional sources of animal protein. Incorporation of insect farming in other farming enterprises is a good way of diversifying livelihoods and enhancing resilience to climate change (Chandra et al., 2016).

\section{Good Agricultural Practices (GAPS)}

Agroforestry programs

These should be integrated in all aspects of land and natural resources management. Activities such as cutting trees should be prohibited with strictness. As a land use system, agroforestry provides immense benefits such as $\mathrm{CO} 2$ sequestration and enhances soil fertility. Most of these functions have direct benefits for local adaptation while contributing to global efforts to control atmospheric GHG concentrations (Mbow et al., 2013). Agroforestry approaches are sustainable and cheaper. Some of the known agroforestry trees that are of use include: mango (Mangifera indica), Paw paw (Carica papaya), mulberry (Morus alba). Agroforestry provides many of the principles for developing climate-smart agricultural systems (FAO, 2013).

New crop varieties and resistant animal breeds

These can be tolerant to drought conditions and survive heat stress respectively. Climate change greatly affects crop yield by limiting crop growth and development 
(Hatfield and Prueger, 2015) and therefore food crops i.e. maize, beans need to be drought resistant and high yielding. Cash crops like coffee can also be of resistant varieties. An example is the Drought Tolerant (DT) maize varieties that have been developed and tested by the Drought Resistant Maize for Africa (DRMA) project in Eastern and Southern Africa, with superior characteristics. The challenge is adoption due to unavailability of improved seeds, high prices and inadequate information (Fisher et al., 2015). As for animal breeds, some local pastoral groups have kept their indigenous breeds that withstand local conditions although others have made steps to cross breed for resistance, milk and beef production. Generally, breeding improvement programs of African indigenous livestock are still few even when the demand of livestock products is continually increasing (Mwai et al., 2015).

\section{Water storage}

This is one of the biggest challenges that most smallholder farmers still face. This is because most of the technologies required to harvest and store water for a considerable long time require money. Construction of ponds and other surface water storage methods to facilitate micro irrigation should be enhanced. Water harvesting is an integral part in agricultural production to eradicate hunger. In situations where farmers are unable to harvest and store water using dams, reservoirs and tanks, they should conserve soil moisture by mulching, zero tillage and terraces.

\section{Settled farming}

Although migrations are taken as an adaptation strategy to reduce vulnerability to harsh environmental conditions (Ingty, 2017; McLeman and Smit, 2006; Speranza et al., 2009; Yeh et al., 2014), different communities in East Africa have problems relating to land i.e. there is no more land to allow unplanned migrations. This is due to population growth influencing people to protect their land. Governments need to plan and set laws that restrict movement of animals in large numbers to new areas. Farmers should be encouraged to plan agricultural activities which can make individuals develop a sense of responsibility and ownership. Land in East Africa has caused conflicts especially in Uganda.

Maintain and restore degraded ecosystems

Destruction of ecosystems is one of the serious causes of GHGs, which contribute to warming of the Earth. In some communities, forests and swamps have been degraded (Fig. 2). Restoration of damaged ecosystems is key in sequestration of carbon.

\section{Policies}

Climate change policies and laws need to be harmonized to tackle similar challenges facing the region. Policies on agriculture, water management and movements of people need to be updated to reflect current regional problems (Fig. 7). 


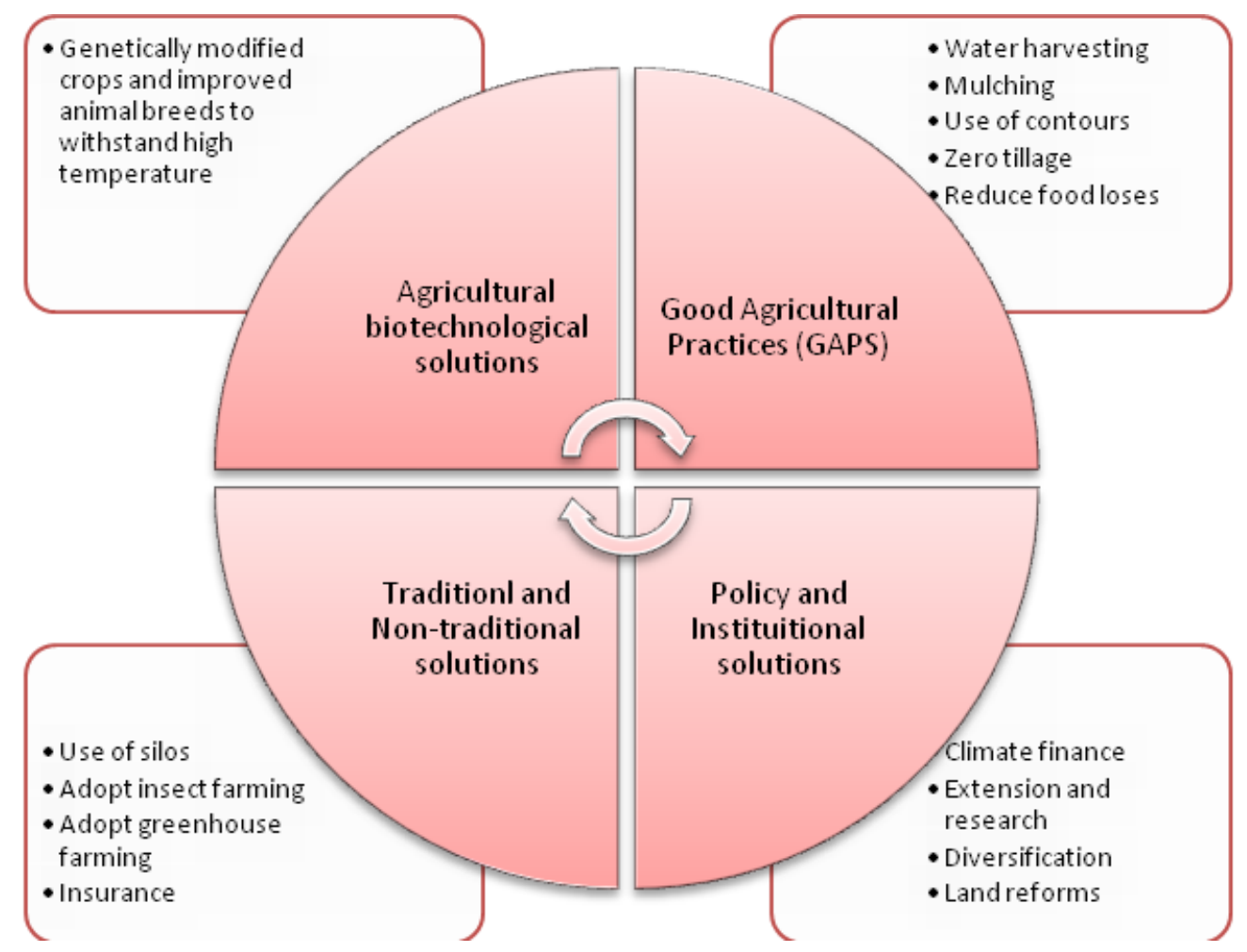

Figure 7. Mitigation and adaptation strategies. (Source: Authors)

Countries should try all possible options to streamline the policies to stabilize food security and increase resilience in agricultural systems (Kelvin et al., 2017). Policies that strengthen institutions and agricultural technologies can improve adaptation and resilience of communities (Shiferaw et al., 2014). Policies need to revive traditional and non-traditional options to fully optimize available options of dealing with climate change and food insecurity.

Policies have to be designed in a way that is integrative across sectors and interlinked but avoid duplication. They should be clear and easy to implement, supported by regional governments to improve resilience of communities to climate change shocks.

\section{Conclusions and recommendations}

Generally, the results of this paper reveal the following:

The destruction of fragile ecosystems by man's ill-judged activities is greatly responsible for climate change in East Africa that in turn causes food insecurity and other disasters.

Simple but useful technologies like use of silos commonly termed as granaries which used to exist and help in preservation of food have slowly been neglected and have contributed to food insecurity.

Farmers sell from their gardens before crops reach maturity stage for harvesting and this exacerbated food insecurity.

We recommend and emphasize integration of traditional and non-traditional measures to guard against food insecurity and climate change. Governments should focus on working out a "solid" policy that protects natural resources like wetlands, 
promotes both traditional and non-traditional technologies and support farmers to adopt new agricultural technologies. This needs synergy across all the East African countries through investment in research, technologies and collaborations to improve on peoples' livelihoods.

There is need to find out why silos and back yard gardens that characterized rural East African communities have reduced yet they would provide cheap sources of food to fight "hidden hunger".

Acknowledgements. This research is funded by Chongqing Research Program for Basic Research and Frontier Technology, No. cstc2016jcyjA0460. We thank the government of Uganda and the Peoples' Republic of China for supporting Natamba's studies. We are indebted to Nuwamanya David, Mugabyomu Jamiah, Mugume Safan, Musimenta Wilber from Uganda and Kamara Albert from Tanzania for photographs that have enriched this manuscript. We appreciate the constructive comments from reviewers that improved the manuscript. Our gratitude goes to Dr. Jeannette W. Cockroft (PhD), Associate Professor, Schreiner University; Kerrville, Texas, USA, for proof reading through the manuscript, Dr. Adelina Mariah Mensah (PhD), Institute of Environment and Sanitation Studies, University of Ghana for providing valuable technical guidance and comments.

Conflict of interest. We declare no conflict of interest.

\section{REFERENCES}

[1] Afedraru, L. (2013): Silos: An efficient way of keeping harvests safely. - Daily Monitor, 13.11.2013. http://www.monitor.co.ug/Magazines/Farming/Silos--An-efficient-way-ofkeeping-harvests-safely/689860-2070622-psimnuz/index.html.

[2] African Union (2017): State of Africa's Population 2017. - Second session of the Specialized Technical Committee on Health, Population and Drug Control (STC-HPDC2) Addis Ababa, Ethiopia.

[3] Amdu, B. (2010): Analysis of Farmers' Perception and Adaptation to Climate Change and Variability: The Case of Choke Mountain, East Gojjam. - MSc Thesis. Addis Ababa University. Addis Adaba, Ethiopia.

[4] Baldwin, A. (2017): Climate change, migration, and the crisis of humanism. - WIREs Clim Change 5:175-197. DOI: 10.1002/wcc.460.

[5] Bryan, E., Ringler, C., Barrack, O., Roncoli, C., Silvia, S., Mario, H. (2013): Adapting agriculture to climate change in Kenya: Household strategies and determinants. - Journal of Environ. Management 114: 26-35.

[6] Capstick, S. W. L., Poorting, W., Pidgeon, N., Upham, P. (2015): International trends in public perceptions of climate change over the past quarter century. - WIREs Clim Change 6: 35-61. DOI: 10.1002/wcc.321.

[7] Chandra, A., Dargusch, P., Karen, E., McNamara, M. C. (2016): How might adaptation to climate change by smallholder farming communities contribute to climate change mitigation outcomes? A case study from Timor-Leste, Southeast Asia. - Sustain Sci. 11(3): 477-492. DOI: 10.1007/s11625-016-0361-9.

[8] Evans, T. E. (1996): The Effects of Changes in the World Hydrological Cycle on Availability of Water Resources. - In: Bazzaz, F., Sombroek, W. (eds.) Global Climate Change and Agricultural Production, pp. 15-48. Wiley, Chichester.

[9] FAO (2001): The State of Food Insecurity in the World. - FAO, Rome.

[10] FAO (2011): Climate change, water and food security. http://www.fao.org/docrep/014/i2096e/i2096e.pdf (accessed on 17th May 2017).

[11] FAO (2013): Climate-smart agriculture sourcebook. - Food and Agriculture Organization, Rome. 
[12] FAO (2016): Strengthening agricultural water efficiency and productivity on the African and global level. Status, performance and scope assessment of water harvesting in Uganda, Burkina Faso and Morocco. - FAO, Rome.

[13] FAO FORESTRY PAPER (2013): Edible insects: future prospects for food and feed security. - FAO, Rome.

[14] FAO, IFAD, WFP (2015): The State of Food Insecurity in the World 2015. Meeting the 2015 international hunger targets: taking stock of uneven progress. - FAO, IFAD, WFP, Rome.

[15] Federal Democratic Republic of Ethiopia (FDRE) (2011): 'Ethiopia's Climate-Resilient Green Economy: Green Economy Strategy, Addis Ababa, Ethiopia. http://www.uncsd2012.org/content/documents/287CRGE\%20Ethiopia\%20Green\%20Eco nomy_Brochure.pdf.

[16] Fisher, M., Abate, T., Lunduka, R. W., Asnake, W., Alemayehu, Y., Madudu, R. B. (2015): Drought tolerant maize for farmer adaptation to drought in sub-Saharan Africa: Determinants of adoption in eastern and southern Africa. - Climatic Change 133: 283. https://doi.org/10.1007/s10584-015-1459-2.

[17] Francesco, F., Jessica, F., Emile, F. (2011): The role of food and nutrition system approaches in tackling hidden hunger. - Int J Environ Res Public Health 8(2): 358-37. DOI: $10.3390 /$ ijerph8020358.

[18] Gichangi, E. M., Gatheru, M., Njiru, E. N., Mungube, E. O., Wambua, J. M., Wamuongo, J. W. (2015): Assessment of climate variability and change in semi-arid eastern Kenya. Climatic Change 130(2): 287-297. https://doi.org/10.1007/s10584-015-1341-2.

[19] Hatfield, J. L., Prueger, H. J. (2015): Temperature extremes: Effect on plant growth and development. - Weather and Climate Extremes 10(A): 4-10. doi.org/10.1016/j.wace.2015.08.001.

[20] Human Rights Watch (2015): "There is No Time Left Now". Climate Change, Environmental Threats, and Human Rights in Turkana County, Kenya. https://www.hrw.org/sites/default/files/report_pdf/kenya1015_web.pdf (accessed on 16th May 2017).

[21] Speranza, I. S. C., Kiteme, B., Ambenje, P., Wiesmann, U., Samuel, M. (2009): Indigenous knowledge related to climate variability and change: insights from droughts in semi-arid areas of former Makueni District, Kenya. - Clim Chang 100: 295-315. https://doi.org/10.1007/s10584-009-9713-0.

[22] Ingty, T. (2017): High mountain communities and climate change: adaptation, traditional ecological knowledge, and institutions. - Climate Change 145(1): 41-55. DOI: 10.1007/s10584-017-20803.

[23] Inter-Agency Working Group on Disaster Preparedness for East and Central Africa (IAWG) (2017): Lessons learned? An urgent call for action in response to drought crisis in the Horn of Africa. - Paper produced for a meeting of the Inter-Governmental Authority for Development (IGAD) in Addis Ababa, Ethiopia, 19-21 January 2017. https://www.nrc.no/globalassets/pdf/briefing-notes/hoa-drought-crisis-call-to-action--iawg---with-nrc-sign-on---20-1-2017.pdf.

[24] Intergovernmental Panel on Climate Change, Climate Change [IPCC] (2001): Impacts, Adaptation and Vulnerability, Contribution of Working Group II to the Third Assessment Report of the Intergovernmental Panel on Climate Change (McCarthy, J. J. (ed.)). Cambridge Univ. Press, Cambridge, UK.

[25] Isunju, J. B. Kemp, J. (2016): Spatial temporal analysis of encroachment on wetlands: a case of Nakivubo wetland in Kampala, Uganda. - Environ Monit Assess 188: 203. DOI: 10.1007/s10661-016-5207-5.

[26] Johnston, I. (2017): Looming 'catastrophe' in East Africa proves why world must tackle climate change, says Oxfarm. - Independent, 27.04.2017. https://www.independent.co.uk/news/world/africa/east-africa-drought-starving-famine- 
catastrophe-climate-change-oxfam-kenya-ethiopia-sudan-somalia-a7704026.html (accessed on 4th May 2017).

[27] Karugia, J. J., Wanjiku, M., Waithaka, S. B. (2011): "Persistence of High Food Prices in Eastern Africa: What Role for Policy?" - Unpublished paper. IFPRI (International Food Policy Research Institute), Washington, DC, and ASARECA (Association for Strengthening Agricultural Research in Eastern and Central Africa), Kampala, Uganda.

[28] Kelvin, M. S., Leigh, W., Jennifer, T., Eitzinger, A., Juan, G. P., Caroline, M., Läderach, P. (2017): Smallholder farmers' attitudes and determinants of adaptation to climate risks in East Africa. - Climate Risk Management 16: 234-245.

[29] Kumsa, T., Gorfu, B. (2014): Beekeeping as integrated watershed conservation and climatic change adaptation: an action research in Boredo watershed. - J Earth Sci Clim Change. 5(7): 213. DOI: 10.4172/2157-7617.1000213.

[30] Labbé, J. F. J., Berrang, F. L., Donnelly, B., Lwasa, S. (2015): Vulnerability to the health effects of climate variability in rural southwestern Uganda. - Mitig Adapt Strateg Glob Change 21: 931-953. DOI: 10.1007/s11027-015-9635-2.

[31] Leal, F. W., Nzengya, D., Muasya, G., Chemuliti, J. (2017): Wanzuu KJ Climate change responses among the Maasai Community in Kenya. - Climatic Change 145(1-2): 71-83. https://doi.org/10.1007/s10584-017-2087-9.

[32] Mbow, C. S. P., Skole, D., Lalisa, D., Mercedes, B. (2013): Achieving mitigation and adaptation to climate change through sustainable agroforestry practices in Africa. Environmental Sustainability 6: 8-14.

[33] McLeman, R., Smit, B. (2006): Migration as an adaptation to climate change. - Clim Chang 76: 31-53. https://doi.org/10.1007/s10584-005-9000-7.

[34] Milly, P. C., Dunne, K. A., Vecchia, A. V. (2005): Global pattern of trends in stream flow and water availability in a changing climate. - Nature 438: 347-350.

[35] Mwai, O., Hannote, O., Kwon, Y. J., Cho, S. (2015): African indigenous cattle: unique genetic resources in a rapidly changing world. - Asian-Australas J Anim Sci 28(7):911921. DOI: 10.5713 /ajas. 15.0002R.

[36] Ojore, G. (2017): Government delivers food relief to Karamoja. The New Vision 6th February, 2017. - http://www.newvision.co.ug/new_vision/news/1445606/governmentdelivers-food-relief-karamoja (accessed on 5th May 2017).

[37] Okoroafor, C. (2017): Marching for the climate: The death of pack animals reiterates the dire situation caused by drought in East Africa. - Venutres Africa, 27.04.2017. https://www.hiiraan.com/news4/2017/Apr/141852/marching_for_the_climate_the_death_ of_pack_animals_reiterates_the_dire_situation_caused_by_drought_in_east_africa.aspx (accessed on 4th April 2017).

[38] OXFAM (2017): A climate in crisis. How climate change is making drought and humanitarian disaster worse in East Africa. - OXFAM Media Briefing, Ref: 01/2017.

[39] Pauline, C., Tafadzwanashe, M., Albert, T. M., Paramu, M. (2015): The potential role of neglected and underutilized crop species as future crops under water scarce conditions in Sub-Saharan Africa. - Int J Environ Res Public Health 12(6): 5685-5711. DOI: 10.3390/ijerph120605685.

[40] Potter, S. (2016): NASA, NOAA data show 2016 warmest year on record globally. https://www.nasa.gov/press-release/nasa-noaa-data-show-2016-warmest-year-on-recordglobally 5th February 2017 (accessed on 10th March 2017).

[41] Ramos, M. C. (2001): Rainfall distribution patterns and their change over time in a Mediterranean area. - Theor. Appl. Climatol. 69(3) 163-170.

[42] Rarieya, M. Fortun, K. (2010): Food security and seasonal climate information: Kenyan challenges. - Sustain Sci 5: 99-114. DOI: 10.1007/s11625-009-0099-8.

[43] Salerno, J. (2016): Migrant decision-making in a frontier landscape. - Environ. Res. Lett. 11: 044019. DOI: 10.1088/1748-9326/11/4/044019.

[44] Shiferaw, B., Tesfaye, K., Kassie, M., Abate, T., Prasanna, B. M., Menkir, A. (2014): Managing vulnerability to drought and enhancing livelihood resilience in sub-Saharan 
Africa: Technological, institutional and policy options. - Weather and Climate Extremes 3: 67-79.

[45] Souverijns, N., Thiery, W., Demuzere, M., Lipzig, V. N. (2016): Drivers of future changes in East African precipitation. - Environ. Res. Lett. 11: 114011.

[46] Spence, A., Poortinga, W., Butler, C., Pidgeon, N. F. (2011): Perceptions of climate change and willingness to save energy related to flood experience. - Nature Climate Change 1: 46-49. DOI: $10.1038 /$ nclimate1059.

[47] Stefan, S. (2012): Africa's hidden hunger. New Internationalist Magazine. People, ideas, and action for global justice. - https://newint.org/features/webexclusive/2012/02/17/africas-hidden-hunger/ (accessed 27th May 2017).

[48] Stott, P. A., Otto, F. E. L., Sun, Y. Vanderlinden, J. P, Oldenborgh, G. J. V., Vaustard, R., Storch, H. V., Walton, P., Pascal, Y., Francis, W. Z. (2016): Attribution of extreme weather and climate-related events. - WIREs Clim Change 7(1): 23-41. DOI: $10.1002 /$ wcc. 380 .

[49] The International Federation's Disaster Relief Emergency Fund (DREF) (2010): Floods and landslides in eastern Uganda. http://www.ifrc.org/docs/appeals/10/MDRUG015fr.pdf.

[50] Witte, F. G. P., Katunzi, E. F. B., Mkumbo, O. C., Seehausen, O., Wanink, J. H., Kawanabe, H., Coulter, G. W., Roosevelt, A. C. (1999): Lake Victoria's Ecological Changes and Their Relationships with the Riparian Societies, Their Cultural and Biological Diversity. - Kenobi Productions, Ghent, Belgium.

[51] Yeh, E. T., Nyima, Y., Hopping, K. A., Klein, J. A. (2014): Tibetan pastoralists' vulnerability to climate change: a political ecology analysis of snowstorm coping capacity. - Hum Ecol 42: 61-74. https://doi.org/10.1007/s10745-013-9625-5.

[52] Yohannes, H. (2016): A Review on Relationship between Climate Change and Agriculture. - J Earth Sci Clim Change 7(2): 335. doi.org/10.4172/2157-7617.1000335. 